\title{
Detection of the Inhibitory Effect of the Leaves, Seed and Fruits of Cydonia oblonga on some Gram Positive and Negative Bacteria
}

\author{
Najlaa A. F. Al- Noamy \\ Department of Biology / College of Science / University of Mosul \\ E-mail: Najlaa lnoamy @ gmail.com
}

(Received 16/6/2019; Accepted 5/11/2019)

DOI: $\underline{10.33899 / \text { rjs.2020.164470 }}$

\begin{abstract}
Seventy six swab samples were collected from Otitis media and stool samples from gastroenteritis cases, were cultured on different culture media, gram positive and gram negative bacteria were isolated and identified. The highest prevalence was Staphylococcus aureus (25\%) while Salmonella typhi formed the lowest isolate rate (3.9\%) other bacterial isolates varied between these two and comparison was done between effect of the air part of Cydonia oblonga (Quince) plant (leaves, seeds, fruits) to determine the highest effective part on the isolated bacteria. As the inhibitory effect of Cydonia oblonga seed, leaves and fruit alcoholic and aqueous extracts on the isolated bacteria were studied. Alcoholic seed extract showed the highest inhibitory activity on two bacterial species Enterobacter aerogenes and Enterococcus faecalis (25 and $22 \mathrm{~mm}$ ) respectively followed by Aeromona sp. and Pseudomonas aeruginosa (13 and $11 \mathrm{~mm})$ respectively while alcoholic leaves extract showed antibacterial effect on Staphylococcus aureus only (15 mm), alcoholic fruit extract showed its effect on Enterococcus faecalis $(12 \mathrm{~mm})$, Klebsiella sp. $(11 \mathrm{~mm})$, Salmonella typhi $(10 \mathrm{~mm})$, and Pseudomonas aeruginosa $(9 \mathrm{~mm})$. the aqueous seed extract showed an effect on Enterococcus faecalis $(11 \mathrm{~mm})$, while the aqueous leaves extract showed the highest effect on Staphylococcus aureus $(20 \mathrm{~mm})$, followed by Bacillus subtilis $(10 \mathrm{~mm})$, and the aqueous fruit extract showed the highest effect on E.coli $(10 \mathrm{~mm})$ while on Enterococcus faecalis, Klebsiella sp. and Enterobacter aerogenes was less $(9 \mathrm{~mm})$ for all of them. The (MIC) value of the effective extracts revealed that the highest value of alcoholic seed extract on E.faecalis was $(25 \mathrm{mg} \backslash \mathrm{ml})$, while the least (MIC) was $(0.39 \mathrm{mg} \backslash \mathrm{ml})$ for Aeromona $\mathrm{sp}$. with the remaining MIC values ranging between the two.
\end{abstract}

Keywords: antibacterial activity, Cydonia oblonga (quince plant).

\section{INTRODUCTION}

Otitis media is a cavity filled with air located in petrous bone cavity. It is one of the most common infections which occur at all ages but is most common in young children. The pathogensis of Otitis media is multifactorial, implicating interaction between the environment, pathogen, local anatomy, and host. Several risk factor have been identified including environmental tobacco smoke exposure, season of the year, respiratory tract infection, and the host immune response to the infections in the middle ear, day care, siblings bottle- feeding (Daly et al., 2010; Uhari et al., 1996).

Gastroenteritis is an infection or inflammation of the digestive system. most gastroenteritis are contagious, it is caused by a number of different micro-organisms including bacteria like (Campylobacter, Salmonella, Shigella) or caused by virus (Rotavirus And Norovirus) or parasites (Giardia, Cryptosporidum). It can also be caused by toxins produced by bacteria examples (Staph.aureus, Enterobacter cloacae, Clostridium perfringenes). the symptoms of infection including diarrhea, vomiting, stomach pain, fever (Meshram et al., 2009; Sulayman and Shareef, 2007; Koneman et al., 1997). 
The development of bacterial resistance to antibiotics has necessitated the studies for new antibacterial agents. It is well known that infectious diseases account for high proportion of health problems, especially in developing countries. Microorganisms have developed resistance to many antibiotics and this property has created expansion of clinical problems in treatment of infectious diseases (Davis, 1994).

The increased resistance to the commercial antibiotics due to the incorrect and miss use of antibiotics treatment of infectious diseases. this case lead the scientists to search for new antimicrobial substances from different sources, such as medicinal plants which have been used for centuries as remedies for human diseases due to its high contents of active components of therapeutic value. The medicinal plant constitute an important part of human food. In addition to its flavoring and preservative effect. In addition to its medicinal uses (Adu, 2009; Betoni et al., 2006).

Cydonia oblonga (Quines plant) is one of the medicinal plants used in alternative medicine for its effect, it is used for intestinal infections, and anti-injury etc.

The taxonomy of Cydonia oblonga Miller (Quince), kingdom Plantae, order Rosales, family Rosaceae, genus Cydonia (Mill), species C.oblonga (Potter et al., 2007; Townsend and Guest, 1966).

Quince is deciduous shrub or small tree leaves were entire, petiolate. The flowers were solitary, terminal usually rather large petals. fruit have many seeds. These plants originate from central Asia and distributed in Iraq, Syria and Turkey (Fattuch et al., 2007; Townsend et al., 1980; Townsend and Guest, 1966).

The fruits subglobose or pyriform, 6-10 $\mathrm{cm}$ or larger, yellowish, hard and sour, however the fruit becomes palatable on cooking and owing to its pleasant aroma has long been used in many countries for marmalade, pies, jellies. The fruit is astringent expectorant, as atonic for cardiac patients.

The seeds are highly mucilaginous, and used as a demulcent, expectorant and tonic effect has been widely known since antiquity and are used till this day in Iraq popular remedies for couphs, bronchial and other complaints, intestinal infections, antidiarrheal, anti-gastrointestinal, antivomating (Jber, 2009; Chackravarty, 1976). The useful effect of the fruit, seeds and leaves of quines to human was due to its content of many vitamins like vitamin $\mathrm{A}$ and $\mathrm{B}$ in addition to other constituents including sulphat, phosphorus calcium, magnesium, choride, potassium and fibers, pectine, acids and many active substances like phenols and glycosides (Rop et al., 2011; Townsed et al., 1980; Chakravarty, 1976).

The quince fruit is known for its medicinal properties as antioxidant, antimicrobial and anti-injury which have been recently attributed to its active constituent. Quince tree leaves, have also a role in removing free radicals and was considered as anti-hemolytic factors (Osman et al., 2010).

The aim of the study was to investigate the antibacterial effect of seeds, leaves and fruit extracts of Cydonia oblonga and to compare the anti-effects against the isolated bacteria.

\section{1- Materials:}

\section{MATERIALS AND METHODS}

\section{A- Isolation and Identification of Bacteria:}

\section{A-1- The Specimens:}

Seventy six samples were collected from patient with Otitis media and gastrointritis their ages ranged between (2-40) years from (ENT) and medical unites in Ibn Al- Atheer and Al- Salam hospitals. (51) Ear swab's samples were collected after clinical examination of patients, swabs were transferred to modified stuart transport medium while (25) stool samples were collected in clean container then cultured on primary culture media. 


\section{A-2- Cultural Media:}

\section{A-2-1- Commercial Media:}

The culture media were prepared according to the instructions of company and the $(\mathrm{pH})$ was adjusted and then sterilized by autoclave.

Culture media includes:

Nutrient agar, MacConkey agar, nutrient broth, blood agar, DNase agar, citrate agar, sugar fermentation medium, Mannitol salt agar, Salmonella- Shigella agar, Muller-Hinton agar.

\section{A-2-2- Prepared Culture Media:}

Media were prepared from their components depending on (Difco, 1998; Koneman et al., 1997) such as: Blood agar, Glucose- phosphate pepton water, Starch agar, Mitis salvarius agar base (M 259).

\section{A-3- Stains and Solutions:}

Prepared according to (Macfaddin, 1980; Koneman et al., 1997) including gram's stain, catalase reagent (3\%), oxidase test reagent, kovac's reagent, methyl red reagent, voges- proskauer reagent.

\section{2- Methods:}

\section{- Cultivation on Primary Media:}

The samples were cultured on, MacConkey agar and blood agar, incubated at $(37)^{\circ} \mathrm{C}$ for $(18$ 24) hours and incubated blood agar was incubated in the presence of 5-10\% of $\mathrm{CO}_{2}$.

\section{- Identification:}

It was done depending on colonial characteristics on culture media then smears were prepared and stained with gram stain and examined microscopically for the shape arrangement of cells and their reaction with gram stain.

\section{- Biochemical Tests:}

Differential and selective media were used to identify some of the pathogenic bacteria, then oxidase test, catalase test, coagulase test, DNase test, IMViC reaction, sugar fermentation test, starch hydrolysis tests were performed according to (Tang and Straton, 2006; Koneman et al., 1997).

\section{B- Preparation of Plant Extracts:}

Fresh fruits, leaves and seeds of quince (Cydonia oblonga Mill.) were collected from gardens of Mosul city. The parts were washed and dried at room temperature.

\section{- Preparation of aqueous extracts:}

Fruits and leaves were cut in to smaller parts, then (40) gms from each of fruit, leaves and seeds were added to a flask containing (160) ml of D.W (1: 4) weight: volume, were grinderd using blendor in an ice bath for (60) minutes to disrupt the walls of plant. Kept at (4) ${ }^{\circ} \mathrm{C}$ for (24) hours for macerating, then the mixture was filtered through many layers of gauz, then filtrated again through (Whatmann paper No.1) under vaccume then extract were obtained (Riose, et al., 1987) which was dried by lyphilization in lyophilizer produced by Edwards company then samples were kept in glass vials and stored at $(-20){ }^{\circ} \mathrm{C}$ (Riose et al., 1987; El- Astal et al., 2005).

\section{- Preparation of ethanolic extracts:}

Fruit and leaves were divided in to smaller parts, (20) gm each of the fruit, leaves and seeds were crushed in (200) $\mathrm{ml}$ of ethanol (95) \% in an ice bath, the solution was left in refrigerator for (24) hours then filtered using many layers of gauze, after that alcohol was evaporated using rotary vaccume evaporator, (Electrothermal English company) at $(40){ }^{\circ} \mathrm{C}$. a thick layer of extract which was left kept in glass vials at $(-20){ }^{\circ} \mathrm{C}$ (Adomi, 2006; El- Astal et al., 2005).

\section{- Sterilization of aqueous and ethanolic extract:}

One gm of dried plant extract was dissolved in (5) $\mathrm{ml}$ of D.W to prepare an extract concentration (200) $\mathrm{mg} \backslash \mathrm{ml}$ as standard concentration which was sterilized by filteration using Millipore filter $(0.22 \mu)$. serial dilutions was prepared from the stock solution. While when prepared the ethanolic extract one gm of plant extract was dissolved in (5) $\mathrm{ml}$ of dimethyl sulfoxide to 
prepare concentration of (200) $\mathrm{mg} \backslash \mathrm{ml}$ as a stock solutions which was sterilized by pasteurization at (62) ${ }^{\circ} \mathrm{C}$ for $30 \mathrm{Sec}$.

\section{- Determination of the antimicrobial activity:}

The disk diffusion method by (Bauer et al., 1966) was used, the bacterial suspensions were prepared then the bacterial concentrations were fixed at $1.5 \times 10^{8}$ cell $\backslash \mathrm{ml}$ by comparsion with MacFarland standard No. 1, then a sterile cotton swab were impregnated with the broth culture which was rotated several times with firm pressure on the inside wall of the tube to remove excess fluid, then dried surface of the Mueller Hinton agar plate were seeded by streaking the swab three times over the entire agar surface by rotating the plate $60^{\circ}$ after each streak, then filter paper disc impregnated with a stock of aqueous extracts of each (seeds, fruits and leaves) were distributed on surface of plate and disc soaked with ethanolic extract of each (seed, fruit and leaves) on another Mueller Hinton agar plate by using sterile forceps, and plates were incubated at $35^{\circ} \mathrm{C}-37^{\circ} \mathrm{C}$ for (16-18) hr. the antimicrobial activity was determined by observing the diameter of inhibitory zone around the disks (Parija, 2007; Vandepitte et al., 2003).

\section{- Determination of the minimum inhibitory concentration of the plant extracts (MIC):}

Serial dilutions of plant extracts were prepared in (DMSo) for ethanolic extract and in distilled water for aqueous extract $(200,100,50,25,12.5,6.25,3.125,1.56,0.78,0.39,0.195)$ $\mathrm{mg} \backslash \mathrm{ml}$ then $(0.1) \mathrm{ml}$ of each concentration was added to $(9.8) \mathrm{ml}$ of sterile nutrient broth and (0.1) $\mathrm{ml}$ of standard bacterial suspension $\left(1.5 \times 10^{8}\right)$ cells $\backslash \mathrm{ml}$ was added to all tubes then incubated at $37^{\circ} \mathrm{C}$ for $24 \mathrm{hr}$.

The tubes were examined for turbidity which was regarded as an indicator of the bacterial growth. The lowest concentration of extracts which inhibits the bacterial growth and was detected by lack of visual turbidity, was regarded as the MIC (Rios and Recio, 2005; Koneman et al., 1997).

\section{RESULTS AND DISCUSSION}

During the period of study (76) samples were collected from patient infected with Otitis media and gastroenteritis including ear swab and stool samples. Table (1) showed the percent of isolation of each bacterial species, Staph.aureus and Bacillus subtilis formed the highest isolates $(25 \%)$ and $(18.4 \%)$ respectively, while Salmonella typhi was the lowest (3.9\%), the other bacterial isolates ranged between them. Our results showed predominance of Staph.aureus in patient infected with Otitis media which accounts for $(25 \%)$ these results are similar to study of (Jwad, 2011) who isolate Staph.aureus at ratio of $(24.6 \%)$ and also to the result of (Al- Maadidi, 1999) who isolate it at ratio of $23.4 \%$ (Al-Faris et al., 1998) and (Khalil, 1980) confirmed that Staph.aureus constitute the highest isolation rate between other bacterial causes of infection.

The present study showed that B.subtilis was isolated from Otitis media (18.4\%). Bacillus sp. considered normal flora of external auditory canal and skin and also it is present in air as contamenant and hence isolated at a high rate (Al- Madidi, 1999). also isolate this bacterium in the a second class from samples of the control group. its isolation may be a results of contamination of otoscope.

E.faecalis and E.aerogenes constitute the highest rate of isolation from stool (6.57\%) while Salmonella typhi was isolated at a lower rate (3.9\%). Gastroenteritis was caused by many species of bacteria which was isolated at from cases and cause inflammatory changes through their invasion and production of enterotoxins in the intestine leading to diarrhea (Meshram et al., 2009; Winn et al., 2006). 
Table 1: The percentage of isolated bacterial species

\begin{tabular}{|c|c|c|c|}
\hline Isolated bacterial species & Source & Number & Percentage \% \\
\hline Staphylococcus aureus & O.m & 19 & 25 \\
\hline Bacillus subtilis & O.m & 14 & 18.42 \\
\hline Pseudomonas aeruginosa & O.m & 9 & 11.84 \\
\hline E.coli & O.m, stool & 7 & 9.21 \\
\hline Klebsiella sp. & o.m & 6 & 7.89 \\
\hline Enterococcus faecalis & stool & 5 & 6.57 \\
\hline Enterobacter aerogenes & stool & 5 & 6.57 \\
\hline Morganella morganii & stool & 4 & 5.29 \\
\hline Aeromonas sp. & O.m, stool & 4 & 5.27 \\
\hline Salmonella typhi & stool & 3 & 3.94 \\
\hline & & $\mathbf{7 6}$ & $\mathbf{1 0 0 \%}$ \\
\hline
\end{tabular}

O.m. = Otitis media

The antibacterial effect of the quines extract:

The results showed that the alcoholic extract of quinus plant tend to inhibit the growth of bacteria compared with aqueous extract, (Table 2) showed the antibacterial activity of quinus extracts against bacteria. The results showed that C.oblanga (quince) seeds ethanolic extract showed high antibacterial effect against E.aerogenes and E.faecalis (Fig. 1 and 2), and lower effect on Aeromonas sp. and the extract showed low effect on Pseudomonas aeroginosa. while no effect had been shown by the aqueous seeds extract against all the species of bacteria except E.faecalis which showed a clear effect as the inhibitory zone $(11 \mathrm{~mm})$.

Table 2: The antibacterial effect of the aqueous and ethanolic extract of quines plant on isolated bacteria

\begin{tabular}{|c|c|c|c|c|c|c|}
\hline \multirow{2}{*}{ Bacterial species } & \multicolumn{6}{|c|}{ Plant extract of quines plant } \\
\cline { 2 - 7 } & $\begin{array}{c}\text { ethanolic } \\
\text { seeds } \\
\text { extract }\end{array}$ & $\begin{array}{c}\text { aqueous } \\
\text { seeds } \\
\text { extract }\end{array}$ & $\begin{array}{c}\text { ethanolic } \\
\text { leaves } \\
\text { extract }\end{array}$ & $\begin{array}{c}\text { aqueous } \\
\text { leaves } \\
\text { extract }\end{array}$ & $\begin{array}{c}\text { ethanolic } \\
\text { fruit } \\
\text { extract }\end{array}$ & $\begin{array}{c}\text { aqueous } \\
\text { fruit } \\
\text { extract }\end{array}$ \\
\hline Staph.aureus & - & - & 15 & 20 & - & - \\
\hline E.faecalis & 22 & 11 & - & - & 12 & 9 \\
\hline Pseudo.aeruginosa & 11 & - & - & - & 9 & - \\
\hline Aeromonas sp. & 13 & - & - & - & - & - \\
\hline E.coli & - & - & - & - & - & 10 \\
\hline Morganella morganii & - & - & - & - & - & - \\
\hline Salmonella typhi & - & - & - & - & 10 & - \\
\hline Klebsiella sp. & - & - & - & - & 11 & 9 \\
\hline Bacillus subtilis & - & - & - & 10 & - & - \\
\hline Enterobacter aerogenes & 25 & - & - & - & - & 9 \\
\hline
\end{tabular}

(- = no activity)

The aqueous leaves extract showed high effect on Staph.aureus $20 \mathrm{~mm}$ Fig. (3), while on Bacillus subtilis it was $(10 \mathrm{~mm})$ ethanolic leaves extract don't showed effect on bacteria except on Staph.aureus which give inhibitory zone of $15 \mathrm{~mm}$ Fig. (4). Ethanolic fruit extract showed had high effect on E.faecalis $(12 \mathrm{~mm})$, while low inhibitory effect on other species of bacteria. the aqueous fruit extract showed a very low activity on E.faecalis, Klebsiella sp. and E.aerogenes, $(9 \mathrm{~mm})$, while the inhibitory zone on E.coli $(10 \mathrm{~mm})$ from this results the antibacterial effect depends primarily on the type of solvent used for extraction it was observed that the ethanolic extract of 
C.oblonga seeds was the most effective against tested bacterial however the aqueous extract showed insufficient effect and most species of bacteria were resistant to it. This results was similar to the study of (Cloch et al., 2017; Alizadeh et al., 2013).

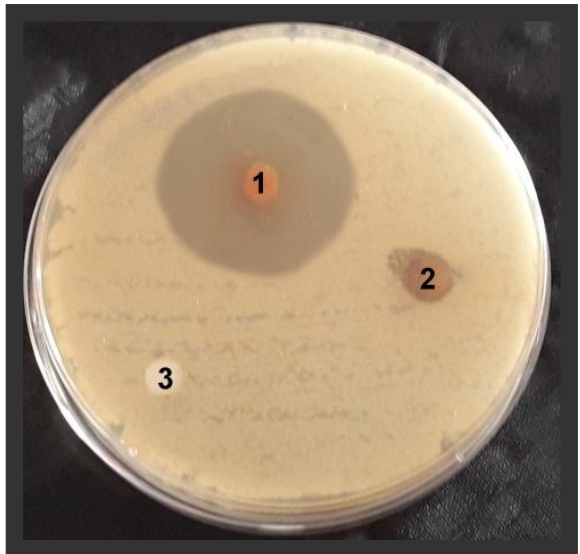

Fig. 1: Antibacterial activity of Quince seeds alcoholic extract on E.aerogenes (1= seeds, 2 = fruit, $3=$ leaves $)$

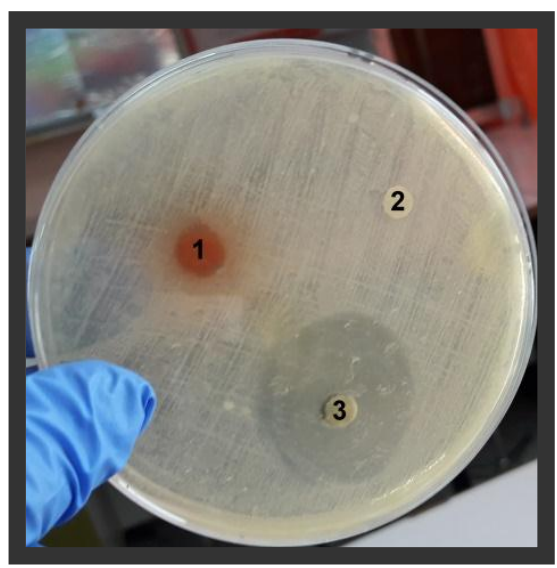

Fig. 3: Antibacterial activity of Quince aqueous leaves extract on Staph.aureus ( $1=$ seeds, $2=$ fruit, $3=$ leaves $)$

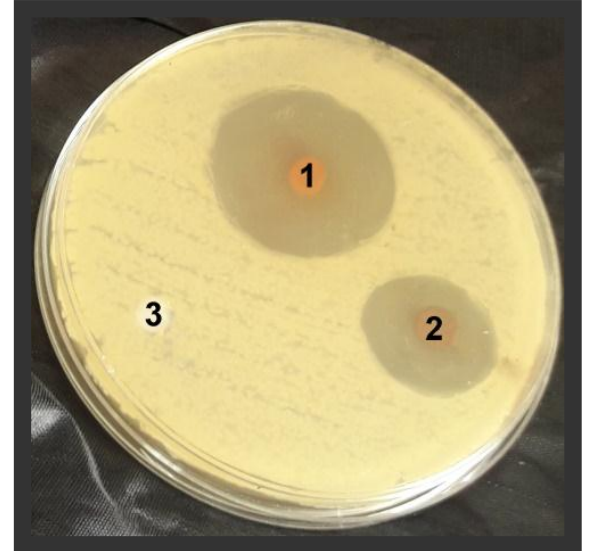

Fig. 2: Antibacterial activity of Quince seeds and fruit alcoholic extract on E.faecalis (1= seeds, $2=$ fruit, $3=$ leaves $)$

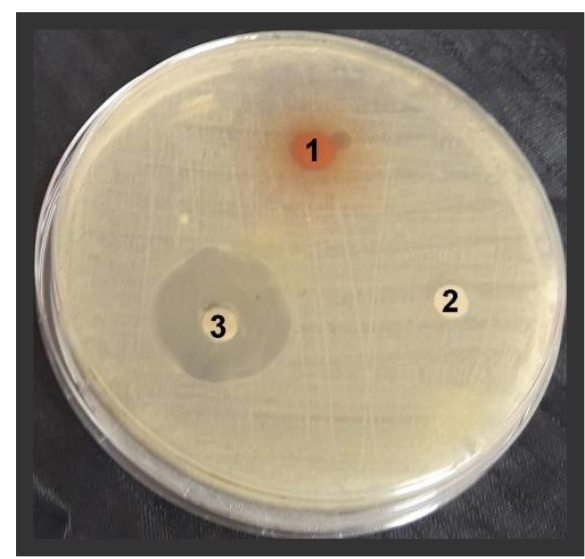

Fig. 4: Antibacterial activity of alcoholic leaves extract on Staph.aureus ( $1=$ seeds, 2 = fruit, $3=$ leaves $)$

The study of (Shahata et al., 2011) showed that the effect of ethanolic seeds toward Staph.aureus, Streptococcus pneumoniae, K.pneumoniae and Pseudo.aeruginosa gave different diameters of inhibition zone at different concentration of extracts used.

The inhibitory effect of quines seeds was referred to its contents of active substances like glycosides, phenols, tannines, ratenges, comarens and oily materials (Shahata et al., 2011) and the study of (Alizadeh et al., 2013) showed the main aromatic compounds of Cydonia oblonga were five including caryophyllene, Eucalyptol, camphor, morphinan-3, 6- \pm diol, 7, 8- did hydro-4, 5- \pm epoxy- 17- methyl-, 6- acetate and trimethyl hydrazine which were identified by GC- MS method. The dissimilarity of the effect of extract toward the bacterial isolates was due to dissimilarity of the methods used for extraction and differential content of active materials. 
The result of our study were similar to that of (Shahata et al., 2011) with respect to the effect of alcoholic seeds extract on Pseudomonas aeroginosa was moderate (14 mm), and our results were similar to the study of (Alizadeh et al., 2013) the Enterobacteriaceae were sensitive to quenes extract, while (Cloch et al., 2017) showed that no inhibitory effect had been detected using the alcoholic leaves extract against E.coli, Pseudomonas, and Bacillus, these results were similar to our results, while the aqueous leaves extract inhibited the growth of E.coli, Pseudomonas, and Bacillus, our results inhibited Bacillus subtilis and Staph.aureus only.

Our results was consistent with that of (Al-Abacee, 2016) with respect to the effect on Staph.aureus. The effect of leaves extracts was due to presence of active constituents as tannines and pectins. The seeds extract showed better activity than leaves extract because the content of active materials were more than leaves extract. The aqueous fruit extract showed the effect on E.coli in our result is similar to (Cloch et al., 2017).

The extracts obtained from different parts of the same plant showed various activity against bacteria under study the aqueus leaves extracts was characterized by stronger effect on bacteria than fruit extracts. The study of (Silva et al., 2005) showed different polyphenol composition of individual morphological parts of quince. The leaves extract contain flavonol glycosides, derivative of quercetin and phenolic acid which are present at low concentration in fruit extract.

The composition of the various parts of the same plant is directly related to the degree of its maturity and its exposure to environmental conditions. The content of poly phenolic compounds changes during growth and ripening of quince, which may affect its antimicrobial properties (Wojdylo, 2011).

Table (3) showed the minimum inhibitory concentration (MIC) for Cydonia oblonga Miller extract toward the tested bacterial species. Its appeared that the MIC of E.aerogenes equal to (0.78) $\mathrm{mg} \backslash \mathrm{ml}$ for ethanolic seeds, Fig. (5), while MIC of Staph.aureus equal to (3.125) $\mathrm{mg} \backslash \mathrm{ml}$ for equeos leaves Fig. (6) and (6.25) $\mathrm{mg} \backslash \mathrm{ml}$ for ethanolic leaves extract, while Aeromonas sp. equal to (0.39) $\mathrm{mg} \backslash \mathrm{ml}$ for ethanolic seeds, and E.faecalis was (25) $\mathrm{mg} \backslash \mathrm{ml}$ for the same extract.

Table 3: Minimum inhibitory concentration (MIC) of quines plant extract on tested bacteria

\begin{tabular}{|c|c|c|c|}
\hline Bacterial species tested & $\begin{array}{c}|c| \\
\text { Qthanolic seeds } \\
\text { extract }\end{array}$ & $\begin{array}{c}\text { aqueous leaves } \\
\text { extract }\end{array}$ & $\begin{array}{c}\text { ethanolic leaves } \\
\text { extract }\end{array}$ \\
\hline E.aerogenes & $0.78 \mathrm{mg} \backslash \mathrm{ml}$ & - & - \\
\hline Staph.aureus & - & $3.125 \mathrm{mg} \backslash \mathrm{ml}$ & $6.25 \mathrm{mg} \backslash \mathrm{ml}$ \\
\hline Aeromonas $\mathrm{sp}$. & $0.39 \mathrm{mg} \backslash \mathrm{ml}$ & - & - \\
\hline E.faecalis & $25 \mathrm{mg} \backslash \mathrm{ml}$ & - & - \\
\hline
\end{tabular}

(- = no activity)

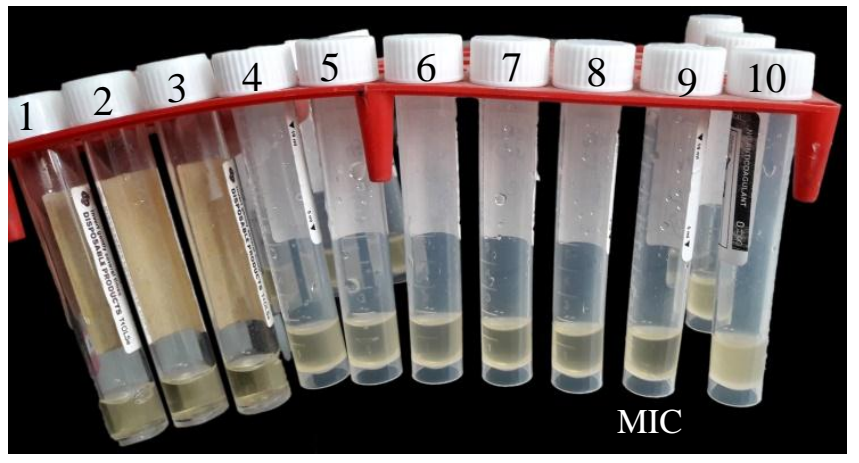

Fig. 5: MIC of E.aerogens $(\mathrm{MIC}=0.78 \mathrm{mg} / \mathrm{ml})$

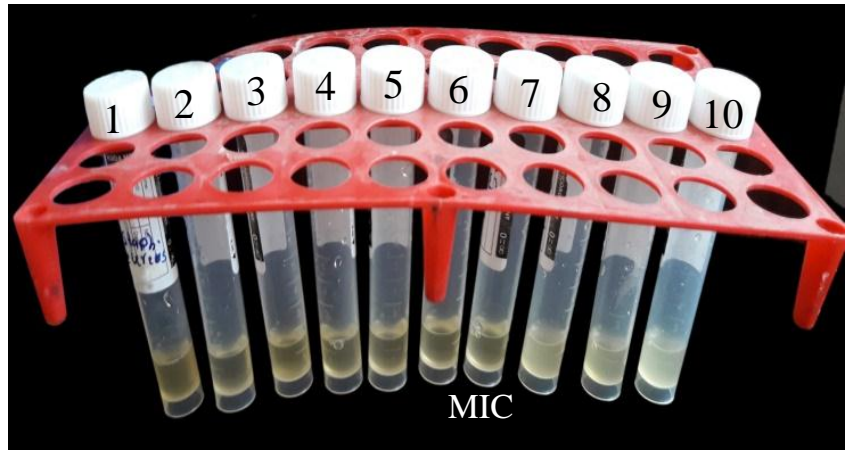

Fig. 6: MIC of Staph.aureus

$(\mathrm{MIC}=3.125 \mathrm{mg} / \mathrm{ml})$ 
The main components responsible for the antimicrobial properties of plant are poly phenolic compounds, the mode of effect of the active materials were by inhibitory the enzymes (phospholipase oxygenase) through binding with hydrosulfide groups and stops the activation of proteins (Al-Hadidi et al., 2013; Cowan, 1999; Kim et al., 1995).

Tannins protect a plant against the effects of microorganisms by the formation of complexes with proteins, while terpenes interfere with the incorporation of the lipophilic compounds in the bacterial cell membrane (Mendoza et al., 1997).

The differences of the antibacterial activity compared with other studies may be due to many factors including local, seasonal, climatic and the experimental factors.

\section{CONCLUSION}

The extract obtained from different parts of the same plant exhibited various activity against studied bacteria, and the ethanolic seeds of quines plant showed the highest effect against the bacterial species compared with aqueous extract, and the equeus leaves extracts showed better antibacterial activity against Staph.aureus and the effect of seeds and leaves extracts was the more effective.

\section{REFERENCE}

Adomi, P.O. (2006). Antibacterial activity of aqueous and ethanol extracts of the stem bark of Alstonia boonie and morinda lucida. Sci. Res. Essays., 1(2), 50-53.

Adu, F.; Gbedema, E.Y.; Annan, K. (2009). Antimicrobial and resistance modulatory activities of corynan the pachyceras. Pharm. Re. 1(5), 280- 284.

Al- Abacee, H.H. (2016). Effect different concentrations of aqueous extract of some plants on some bacteria in vetro. J. Alkufa Agr. Sci. 8(4), 166-183.

Al-Faris, E.A.; Abdughani, H.; Mukhdomi, G.H.; Kambal, A.; Al- Muhaimeed, H.S. (1998). Microbiology and antimicrobials sensitivity of supportive Otitis media. Saudi. Med. J., 19(4), 417- 422.

Al-Hadidi, K.A.; Al-Numan, A.Y.; Al-Daody, A.C. (2013). Interaction between some phenolic compounds in ammi majus herb (khillah) extracts and antibiotics against some selected bacterial isolates in vitro. Raf. J. Sci., 24(2), 17-30.

Alizadeh, H.; Rahnema, M.; Semnani, S.N.; Hajizadeh, N. (2013). Detection of compounds and antibacterial effect of quince (cydonia oblanga Miller) extract in vitro and in vivo. TBAP 3 (5 and 6), 303-309.

Al-Maadidi, J.F.A. (1999). Studies of micro- organisms causing supportive Otitis media in children in Mosul City. M. Sc. thesis, University of Mosul.

Bauer, A.W.; Kirbay, W.A.M.; Sherris, J.S.; Turk, M. (1966). Antibiotic susceptibility testing by a standardized single disc method. Am. J. Clin, pathol., 45, 493- 496.

Betoni, J.F.C.; Mantovani, R.P.; Barbaso, L.N.; Di-Stasi, L.C.; Fernandes, A. (2006). Synergism between plant extract and antimicrobial drugs used on Staphylococcus aureus diseases. $J$. Memorias do in stituto oswaldo cruz. 101(4), 387- 390.

Chakravarty, H.L. (1976). "Plant Wealth of Iraq". A dictionary of economic plants vol. 1, Botany directorate, Ministry of Agriculture and Agrarian reform, Baghdad, Iraq, 45 p.

Cloch, M.; Satora, P.; Skotniczny, M.; Semik- Szczurak, D.; Tark, T. (2017). Polish. J. Microbio. 66, 4,463- 472.

Cowan, M.M. (1999). Plant products as antimicrobial agents. Clin. Microbiol. Rev. 8, 564- 582.

Daly, K.A.; Hoffman, H.J.; Kaverner, K.J.; Kvestad, E.; Casselbrant, M.L.; Homoe, P. (2010). Epidemiology, natural history, and risk factors: panel report from the Ninth international Research conference on Otitis media. Int. J. Pediatr Otorhinoluryngol, 74, 231-40.

Davis, J. (1994). In activation of antibiotics and the dissemination of resistance genes. Sci. 264 (5157),375-382. 
Difco Manual (1998). $11^{\text {th }}$ edition by difco laboratories division of becton Dickinson and company sparks, Mary Land 21152. USA.

El-Astal, Z.Y.; Ashour, A.; Kerrit, A.A.M (2005). Antimicrobial activity of some medicinal plant extracts in Palestine. Pak. J. Med. Sci, 21(2), 187-193.

Fattouch, S.; Caboni, P.; Coroneo, V.; Tuboroso, C.I.; Angioni, I., Dessi, S.; Marzouki, N.; Cabras, P. (2007). Antimicrobial activity of Tunisian quince (cydonia oblanga Miller) pulp and peel poly phenolic extracts. J. Arg. food Chem. 55(3), 963-969.

Grand, A.; Verpoort, R.; Wondergem, P.A.; Pousset, J.L. (1988). Anti- infections phytotherapies of the tree- savannah sengal (West- Africa), H- Antimicrobial activity of 33 specise. $J$. Ethnopharmaco., 22, 25-31.

Jber, R.M. (2009). "Botany Pharmacology". part 2, Arabic community library for publishing, Aman, Jordan, $44 \mathrm{p}$.

Jwad, J.S. (2011). Bacteriological study of Otitis media infection in Baquba city. Diyala J. Pure Sci., 7, 2,102-112.

Khalil, H.L. (1980). The bacteria causing Otitis media in different age groups in Mosul area. M. Sc. Thesis, University of Mosul.

Kim, J.; Marshall, M.R.; Wei, C. (1995). Antibacterial activity of some essential oils components against five foodborne pathogens. J. Agric. Food Chem. 43, 2839- 2845.

Koneman, E.W.; Allen, S.D.; Janda, W.M.; Schreckenberg, P.C.; Winn, W.C. (1997). "Color Atlas and Textbook of Diagnostic Microbiology". $5^{\text {th }}$ ed. J.B. Lippincottcom, Philadelphia, New York.

Macfaddin, J.F.M. (1980). "Biochemical Test for Identification of Medical Bacteria", Williams and Willkins, Inc., Baltimore, USA.

Mendoza, L.; Wilkens, M.; Urzua, A. (1997). Antimicrobial study of the resinous exudated and of diterpenoids and flavonoids isolated from some Chilean psedognophalium (Asteraceae). $J$. Ethnoph. 58, 85- 88.

Meshram, M.; Ravikanth, K.; Maini, S.; Rekhe, D.S. (2009). Treatment of clinical cases of bacterial enteritis in goat with new polherbal antidiarrhoeal formulation. Vet. Wld., 2(4), 143-145.

Osman, A.G.; Koubtb, M.; Sayed, Ael D. (2010). Use of hematological parameters to assess the efficiency of quince (Cydonia oblanga Miller) leaf extract in elleviation of the effect of ultraviolet- Aradiation on African catfish clarias gariepinus. J. Photo chem. and photobio. 99 (1), 1-8.

Parija, S.C. (2007). "Text Book of Practical Microbiology". Ahuja publishing house. New DelhiIndia, pp. 92-94.

Potter, D.; Eriksson, T.; Evans, R.C.; Oh, S.; Smedmark, J.E.; Dickinson, T.A. (2007). Phylogeny and classification of rosacea. Plant Sys. and Evol., 266 (1-2), 5-43.

Rios, J.I.; Recio, M.C. (2005). Medicinal plants and antimicrobial activity. J. Ethnopharmaco., 100 (1-2), 80-84.

Riose, J.L.; Recio, M.C.; Villay. A. (1987). Antimicrobial activity or selected plant employed in the Spanish Mediterraneam area. J. Ethnopharmaco., 21, 139-152.

Rop, O.; Balik, J.; Reznicek, V.; jurikova, T.; Skardova, P.; Salas, P.; Schoror, J.; Mlcek, J.; Karamarova, D. (2011). Chemical characteristics of fruits of some selected quince (cydonia oblanga mill.) cutlivars Czech. J. food Dsci., 29(1), 65-73.

Shahata, H.A.; Athman, S.H.; Azez, F.M. (2011). The study of antibacterial activity of some plant extracts against causes of pneumonia, J. Baghdad Sci. 8(2), 248-254.

Silva, B.M.; Andrade, P.B.; Seabra, R.M.; Oliverira, M.B.P.P.; Ferreira, M.A.; Ferrerse, F. (2005). Composition of quince (cydonia oblanga Miller) seeds: phenolics, organic acids and free amino acids. Natur. Prod. Res., 19, 275-281.

Sulayman, S.D.; Shareef, A.Y. (2007). Detection of some virulence factors of Enterobacter cloacae isolated from children diarrhea cases in Mosul. Raf. J. Sci., 18, 12,23-31. 
Tang, Y.W; Straton, C.W. (2006). "Advanced Techniques in Diagnostic Microbiology". Springer Science and Business Media, Itc. USA.

Townsed, C.; Geuest, E.; Omar, S.A.; Al- Khayat, A.H. (1980). "Flora of Iraq". Vol. 8, Ministry of Agriculture and Agrarian reform, Baghdad.

Townsend, S.C; Guest, E. (1966). "Flora of Iraq". Published by the Ministry of Agriculture of The Republic of Iraq, pp. 106-107.

Uhari, M.; Mantysaari, K.; Niemala, M. (1996). A met analytic review of the risk factors for acut Otitis media. Clin. infect dis., 22, 1079-83.

Vandepitte, J.; Engback, K.; Piot, P.; Heuk, C. (2003). "Basic Laboratory Procedures in Clinical Bacteriology", World Health organization, Genva.

Winn, W.C.; Allen, S.D.; Procop, G.W.; Schreckenberger, P.C.; Janda, W.M.; Woods, G.L. (2006). "Koneman's Color Atlas and Textbook of Diagnostic Microbiology". $6^{\text {th }}$ ed. Lippincott Williams and Willkins, USA.

Wojdylo, A. (2011). "Evaluation of Quince Fruit Use Possibilities in the Manufacture of Processed Products with High Poly Phenols Content and Antioxidant Activity in (Polish)." University of Wroclaw, publishing house in Wroclaw, Wroclaw.

التحري عن الفعالية التثبيطية لأولق وثمار ويذور نبات السفرجل في بعض أنواع البكتريا الموجبة والسالبة لصبغة كرام

\begin{abstract}
الملخص

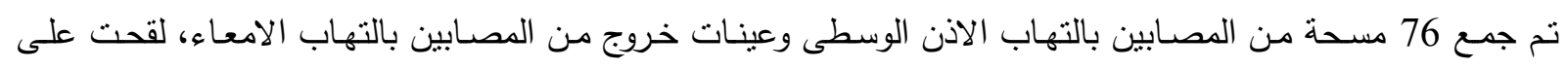

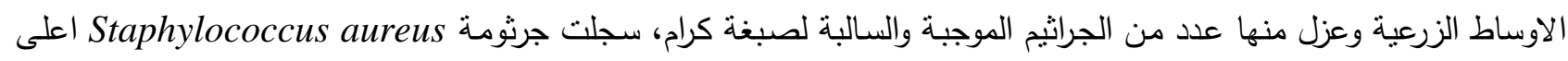
نسبة عزل بلغت (25\%) فيما عزلت Salmonella typhi بأقل نسبة بلغت (3.9\%)، وتراوحت نسب بقية الجراثية وتئ بينهما. قورن

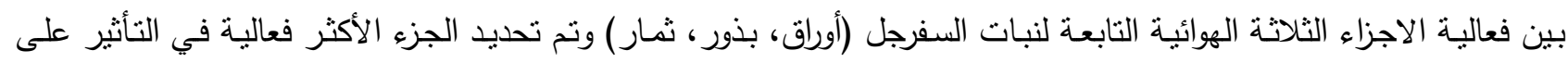
الجراثيم المعزولة.

تم دراسة التأثير التثبيطي لمستخلصات بذور وأوراق وثمار السفرجل المائية والكحولية وتأثيره على جميع الجراثيم المعزولة
\end{abstract}

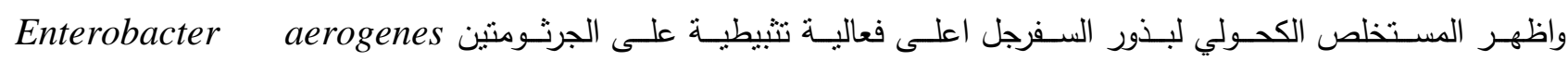

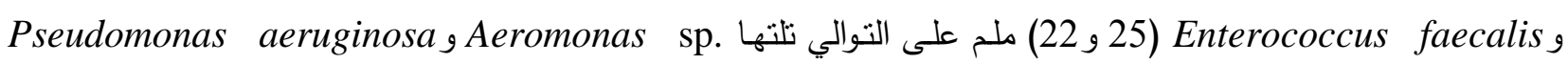

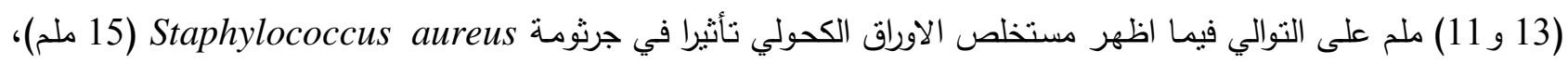

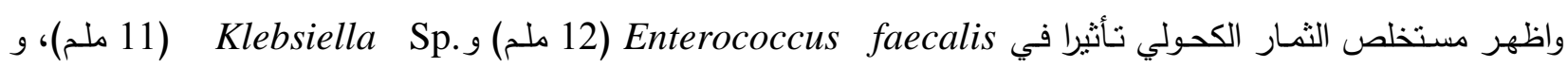
Salmonella typhi Staphylococcus Enterococcus faecalis aureus اما Klebsiella sp. Enterococcus faecalis و و فأظهرت فعالية اقل (9 ملم) لكل منها. وتم تقدير التركيز المثبط (MIC) للمستخلصات المؤثرة على الأنواع الجرثومية حيث بلغت قيمة (MIC) للمستخلص الكحولي لبذور السفرجل على جرثومة E.faecalis (25 ملغم/مل) واقل قيمة (0.39 ملغم/مل) على جرثومة .Aeromonas sp. وتراوحت قيم بقية المستخلصات بينهما. 